\title{
A literatura e a arte em angola na pós-independência
}

\author{
Carmen Lucia Tindó Secco ${ }^{1}$
}

\begin{abstract}
We divide our work into three sections: first, we will raise questions about the concept of post-colonialism; then we will trace a route of Angolan poetry in post-independence, and the last section discusses some important painters of Angola. Our intention is to highlight some trends in Angolan post-1975 literature and painting.
\end{abstract}

Keywords: Postcolonialism, coloniality, post-independence, literature, painting.

Resumo: Dividimos nosso trabalho em três momentos: inicialmente, levantaremos questões acerca do conceito de pós-colonialismo; a seguir, traçaremos um percurso da poesia angolana na pós-independência; na última parte, apresentaremos alguns pintores importantes de Angola. Nossa intenção é evidenciar algumas tendências da literatura e pintura angolanas-pós 1975.

Palavras-chave: - Pós-colonialismo, Colonialidade, Pós-independência

“Pós-colonialismo”, “Colonialidade”, “Pós-Independência”: conceitos e questionamentos

Com suas independências, as ex-colônias portuguesas, politicamente, puseram fim ao colonialismo que as subalternizou durante séculos. No domínio cultural, entretanto, não se libertaram totalmente; até hoje, ainda persistem diferentes formas de "colonialidades internas", uma vez terem sido, durante os anos de dominação, introjetadas diversas heranças do colonialismo não só nos modos de pensar e conhecer, mas também nos de sentir e desejar de grande parte das elites urbanas coloniais.

Aníbal Quijano, Walter Mignolo, Boaventura de Sousa Santos, dentre outros pensadores das questões coloniais e "pós-coloniais", demonstram como alguns legados advindos do colonialismo foram preservados por determinadas "geopolíticas do conhecimento", cujas ações foram, entre outras, as de levarem as burguesias assimiladas das ex-colônias da América do Sul e da África a reduplicarem, muitas vezes, formas de saberes e poderes eurocêntricos.

Boaventura de Sousa Santos (2002), analisando o colonialismo português, concluiu que este foi semiperiférico: Portugal colonizou o Brasil, Moçambique, Angola, Cabo Verde, Guiné-Bissau, São Tomé e Príncipe, de modo predatório; contudo, ao mesmo tempo, também foi colônia da Inglaterra. Essa ambivalência revela, de um lado, o autoritarismo

1 UFRJ e CNPq 
português em relação às colônias e, de outro, a submissão de Portugal frente aos ingleses. Devido a essa ambiguidade, podemos perceber que o término do colonialismo português no Brasil e nas ex-colônias em África não determinou o fim das relações de subalternidade.

Após alertar para essa questão, passamos a definir os significados de "pós-colonialismo", bem como a enumerar algumas críticas que lhe têm sido atribuídas atualmente.

O primeiro sentido de "pós-colonialismo" se prende ao significado do prefixo "pós", referindo-se a tudo que sucedeu as independências das colônias. A crítica que se faz ao termo é que, hoje, vivemos outras formas de "colonialismos", os chamados "neocolonialismos".

O primeiro significado do termo é meramente cronológico e, para os Estudos Culturais surgidos no fim dos anos 1980 e início dos 1990, não tem relevância, pois o mais importante para o campo teórico das reflexões pós-coloniais é o seu caráter transversal que perpassa a Literatura, a História, a Filosofia, a Psicanálise, a Antropologia, a Política. Tal caráter se encontra intimamente relacionado ao segundo significado do termo "pós-colonial" que diz respeito a um "conjunto de práticas e discursos que desconstroem as narrativas coloniais escritas pelos colonizadores, procurando substituí-las por narrativas escritas do ponto de vista dos colonizados". De acordo com essa concepção, o "pós-colonialismo" consiste, portanto, em uma crítica que aponta para as consequências danosas da colonização em culturas colonizadas, buscando subverter as relações de opressão e propiciando visibilidade aos segmentos periféricos. Tal "descentramento" de perspectiva traduz a opção por "ouvir as margens", ou seja, os marginalizados da História. Nesse sentido, enquanto reescrita poética descentrada e disfórica de Angola, a poesia angolana produzida após a Independência pode ser considerada, teoricamente, "pós-colonial".

Todavia, também esse segundo significado de "pós-colonialismo" sofre, contemporaneamente, questionamentos. Um deles é o de que, ao dar voz aos excluídos, faz com que a representação do outro seja segregada em uma espécie de "gueto cultural". O "pós-colonialismo", deixando "falar" somente as margens, acaba por enfatizar o processo de supressão dos subalternos. Ao acirrar a antinomia EU X OUTRO, pode marcar ainda mais a submissão de um em relação ao outro.

Boaventura de Sousa Santos também põe em questão o conceito de "pós-colonial", indagando criticamente: "Será que estes discursos e estas práticas em países (como o Brasil, Angola) colonizados por Portugal, país semiperiférico, não estarão ainda presos a um estatuto colonial de subalternidade, tendo introjetado valores, modelos e cânones eurocêntricos?!".

Diante de tais críticas, preferimos a designação "poesia angolana da pós-independência”, embora essa terminologia também não seja ideal, uma vez se centrar num critério temporal, cronológico.

\section{Trilhas da Poesia Angolana pós-1975}

A Independência e os anos imediatamente a seguir geraram em Angola uma euforia que contaminou grande parte do povo, dos intelectuais, dos poetas, dos escritores, dos pintores. Os dez primeiros anos após o 11 de novembro de 1975 foram o período em que a poesia e as artes em geral deixaram a clandestinidade assumida durante a luta armada para ocuparem um lugar na reconstrução do país.

O movimento editorial cresceu, tendo cabido à União dos Escritores Angolanos, fundada em 10 de dezembro de 1975, um papel de destaque. Isto porque, devido à censura do regime colonial, os poetas, artistas e escritores eram, até então, pouco conhecidos tanto 
dentro, como fora de Angola. No país, muitos eram lidos em exemplares copiografados, o que impedia uma maior divulgação pública. Grande parte dos poetas se inseria tanto no movimento literário, como nas lutas políticas de Independência e na organização do Estado angolano. Agostinho Neto, Costa Andrade, António Cardoso, Jofre Rocha, entre outros, são nomes representativos da poesia revolucionária, nacionalista. Houve, entretanto, poetas que, nesse período, celebraram o 11 de Novembro, intuindo não só a complexidade do momento histórico que envolvia o contexto da Independência angolana, mas também a importância de um trabalho estético renovador. Poemas como "Manhã de 11 de novembro", de Manuel Rui, "Últimas Águas de Novembro", de David Mestre, são textos que, embora tenham cantado a libertação, lançaram um olhar crítico à volta e primaram pela elaboração da linguagem poética.

Podemos afiançar que a Independência despertou o aparecimento de vários textos poéticos celebratórios. Mas, simultaneamente a estes, os anos 1970 em Angola foram também palco da chamada "poesia do gueto" (LARANJEIRA, 1995, p. 134), que se afastava da poética engajada dos anos de luta e se esmerava no labor estético dos versos, sem esquecer, todavia, os conteúdos político-sociais inerentes a diferentes momentos históricos vivenciados pelo contexto angolano. David Mestre - com seu corrosivo humor social -, Ruy Duarte de Carvalho, Arlindo Barbeitos, Jorge Macedo, Manuel Rui, sem dúvida, são poetas representativos dessa "geração 70", não obstante, tenham continuado a escrever pelas décadas subsequentes.

Constatamos, desse modo, que os anos logo a seguir à Independência de Angola foram, de um modo geral, de regozijo e euforia com a liberdade conquistada. O sonho se realizara e a certeza da pátria a ser reconstruída animava grande parte do povo angolano. Até meados de 1985, essa predisposição utópica, até certo ponto, persistiu, refletindo-se, inclusive, num movimento literário novo que se alastrou, com força e entusiasmo, por quase todo o país, principalmente entre os anos de 1980 e 1988: as Brigadas Jovens de Literatura. Surgiu em Luanda, em 5 de julho de 1980, a Brigada Jovem de Literatura de Luanda - BJL, fundada pelo poeta São Vicente, tendo-se constituído como homenagem ao poeta Agostinho Neto, falecido em setembro de 1979. Para saudar a memória do Presidente-Poeta, foram editados por essa Brigada folhetos mimeografados intitulados "Aspiração" e "Caminho das Estrelas", títulos estes inspirados em conhecidos poemas de Neto.

O Movimento das Brigadas foi contagiante e espontâneo, tendo-se espalhado não apenas por diversas províncias angolanas (Luanda, Lubango, Huambo, Cabinda, Uíge e outras), mas também entre angolanos que se encontravam no exterior: em Cuba e na Rússia, por exemplo. Das Brigadas, três foram as mais representativas: a de Luanda; a do Lubango - da Huíla (fundada em 1982) -, cujas produções literárias e ensaísticas circularam no folheto "Hexágono"; e a do Huambo (criada em 1984), denominada "Brigada Jovem de Literatura Alda Lara", cujos poemas e ensaios foram divulgados no folheto "Gênese".

Funcionando como autênticas oficinas literárias, as Brigadas congregaram jovens poetas, mantendo viva e acesa a importância do constante e renovador processo do fazer poético. Tais centros literários serviram não só à discussão crítica e ao repensar dos ideais ideológicos legados por Agostinho Neto e pelas lutas em prol da Independência, mas também ao exercício da liberdade de cada cidadão e ao desenvolvimento da pesquisa estética rumo à renovação da poesia angolana. A poética produzida pelas Brigadas se afastou do tom épico dos poemas de combate que dominaram a cena literária entre 1960 e 1975 , abraçando um viés lírico e uma reflexão profunda acerca de questões humanas e literárias, na esteira da "poesia do gueto" que, nos anos 1970, optou pelo exercício e refinamento da 
elaboração estética, em busca de metáforas dissonantes e surpreendentes. A contribuição dos poetas da geração-1970 (Ruy Duarte de Carvalho, David Mestre, Arlindo Barbeitos) foi fundamental para o desenvolvimento não só da produção literária das Brigadas, como da poesia angolana mais jovem.

Não foi por acaso que grandes poetas hoje consagrados - entre os quais João Maimona, João Tala, Conceição Cristóvão, Fernando Kafukeno e muitos outros - saíram das Brigadas. E destas também emergiram representativos nomes em diversos campos: da Arte, da Política, da Economia, da Administração angolanas, entre outros.

Alguns poetas e intelectuais angolanos mais velhos, entre os quais: Uanhenga Xitu, António Jacinto, Boaventura Cardoso, Jorge Macedo, Luandino Vieira reconheceram a importância das Brigadas. Luandino, inclusive, quando foi Secretário-geral da UEA, deu apoio financeiro a esses movimentos.

No início das Brigadas Jovens, havia ainda uma certa visão utópica em relação à poesia, sendo esta concebida como arma de resistência e conscientização dos jovens, como instrumento de manutenção dos sonhos socialistas preconizados pela Revolução. Porém, após 1985, com o acirramento da guerra desencadeada entre a UNITA e o MPLA, e, especialmente na década de 1990, depois da queda do Muro de Berlim e da dissolução da antiga União Soviética, um tom melancólico passou a envolver a produção poética das Brigadas Jovens, havendo um clima de desencanto em razão do não cumprimento de muitos dos ideais preconizados pela Independência.

Do final dos anos 1980 até 2002, entretanto, as disputas internas entre o MPLA e a UNITA esfacelaram, em grande parte, o crescimento econômico de Angola, destruindo, em grande parte, algumas regiões do país. Nesse período, tanto a poesia das Brigadas Jovens como a de poetas não vinculados a esses Movimentos também se esgarçaram, caracterizando-se por forte distopia em relação aos sonhos libertários. A certeza revolucionária foi, assim, substituída pela instabilidade e pelas incertezas.

No campo da linguagem, a poética pós-1985, de um modo geral, propôs a radicalização do projeto de recuperação da língua literária, aproveitada em suas virtualidades intrínsecas e universais, sem os regionalismos característicos da literatura dos anos 1950 . Erigiu a metaconsciência e o traço crítico como estratégias estéticas prioritárias, afastando-se completamente do panfletarismo ideológico freqüente nos anos 1960. Elegeu a ironia e a paródia como artifícios literários de denúncia da corrupção e das contradições do poder. Dialogando com poetas de gerações anteriores, essa lírica acusou a crise das utopias, fundando um lirismo que cantava, prioritariamente, os sentimentos existenciais. Procedeu a uma intensificação poética, através da depuração da linguagem literária que, em alguns casos, se manifestou por experimentalismos, por corporizações plásticas de palavras, por metáforas surrealistas, por jogos verbais que acentuaram a relação entre ética e estética.

Profunda melancolia recobre, desse modo, grande parte da poética angolana produzida entre 1985-2002 (que abarca tanto o Movimento das Brigadas Jovens e o do Brigadismo Literário, como a poesia produzida fora desses Movimentos).

A par da decepção frente a um social cheio de contradições, muitos poetas continuaram a escrever versos, a maioria dos quais funcionando como instâncias críticas de reflexão acerca dos sofrimentos do povo angolano. Foi, portanto, como resistência que a poesia sobreviveu, ora trilhando os caminhos da sátira e da paródia, ora os da metalinguagem, do erotismo e do amor, ora o dos mitos e dos sonhos. Estes nutriram o sistema literário angolano e, nos tempos presentes, embora um tanto dilacerados, ainda constituem uma espécie de energia subterrânea que impulsiona a imaginação criadora, combatendo o imobilismo e a descaracterização cultural. 
Arlindo Barbeitos - surgido nos anos 1970, mas continuando a escrever até hoje - pode ser identificado como um "poeta dos sonhos", pois é autor, entre tantas obras, de Nzoji - que significa sonho em quimbundo - e Fiapo de sonhos. Usando uma linguagem cortante e surreal, o poeta aponta para: escuras nuvens grossas de outros céus vindas/ entrançando-se por entre asas de pássaros canibais/ e/ chuva de feiticeiro/ em sopro/ de arco-íris dependurada ${ }^{2}$. Nesse poema, o sujeito poético confessa a desilusão por saber dilacerados os antigos sonhos que, no presente, se tornaram difíceis e quase impossíveis de se transformarem em realidade.

Luis Kandjimbo designou como "geração das incertezas" a poesia dos anos 80 e também a dos anos 90, cujos traços constantes são as temáticas da decepção e da angústia diante da situação de Angola frente à fome e à miséria social exacerbadas pela guerra civil entre a UNITA e o MPLA. No entanto, essa poesia pós-1980 não vai, na maioria das vezes, se ater explicitamente às questões sociais. As inquirições por ela feitas não são apenas cognitivas, mas principalmente sensitivas, buscando apreender as paixões humanas em diferentes dimensões. Paula Tavares, José Luís Mendonça, João Melo, Eduardo Bonavena, António Gonçalves, Maria Amélia Dalomba, João Maimona, João Tala, Fernando Kafukeno, Conceição Cristóvão, Lopito Feijoó, Luis Kandjimbo são, por exemplo, alguns desses poetas. Os seis últimos citados pertenceram a Brigadas Jovens de Literatura.

Além das Brigadas, em meados dos anos 1980, há que ressaltarmos o papel da revista Archote, cuja maior contribuição foi a de divulgar, como fizeram nos anos 1950 as revistas Mensagem e Cultura, uma literatura de qualidade. José Luis Mendonça, por exemplo, e outros, como Ana de Santana, publicaram aí alguns de seus textos.

Para João Maimona, poeta que fez parte da Brigada Jovem de Literatura do Huambo, a trajetória da liberdade foi obliterada pela corrupção e as utopias foram mutiladas. Por isso, ele questiona: De quem são os desertos que anunciam lágrimas? ${ }^{3}$

A poesia de Maimona opta pelos caminhos das ruínas e da morte. Esqueletos enchem as mãos do poeta. São imagens alegóricas da fome e da guerra que ocuparam os espaços dos sonhos. Há, todavia, nesses poemas, a par do desencanto, da solidão, da dor, a procura de elementos cósmicos: o ar, o vento, as aves, as abelhas, metafóricas imagens do tecido tênue e aéreo da poesia.

José Luis Mendonça, autor de Chuva novembrina, livro de poemas galardoado com o prêmio de poesia "Sagrada Esperança - 1981" do concurso de literatura "Camarada Presidente", é um dos grandes poetas da novíssima poesia angolana surgida após a Independência, embora não tenha sido membro de nenhuma das Brigadas Jovens de Literatura. Seus poemas produzidos entre os anos 1980 e 1990 apresentam uma visão noturna e melancólica, embora, também, trabalhem com a alegoria da aurora dos sonhos e do amanhecer da poesia.

Alguns poemas de Paula Tavares - grande poetisa que também desponta logo após o 11 de novembro de 1975 e funda uma nova dicção para o discurso poético feminino em Angola - põem em cena, de modo contundente e alegórico, o universo de dor existente no contexto social angolano das guerras pós-independência. O onirismo de seus versos é revelador dos absurdos do próprio real:

2 BARBEITOS, Arlindo. Angola angolê angolema. 2. Ed. Lisboa: Sá da Costa, 1977, p.72.

3 MAIMONA, 1997, p. 81. 
Um homem com o coração nas mãos

correu pela borda da noite

para oficiar as trevas

(...)

Perdeu a capacidade do gesto

(...)

as mãos já não são mãos

mas um tecido de veias

que pingam sangue no útero da floresta ${ }^{4}$

Paula Tavares é autora de obras de poesia: Ritos de passagem (1985), O lago da lua (1999), Dizes-me coisas amargas como os frutos (2001), Ex-votos (2003) e Manual para Amantes Desesperados (2007), além de um romance e de dois livros de crônica em prosa poética. Sua poiesis, embora surgida nos anos 1980, guarda muitas características comuns à poesia angolana dos anos 1970, isto é, da geração de David Mestre e Ruy Duarte de Carvalho.

Outras vozes poéticas femininas também despontaram após 1980, como Ana de Santana, Lisa Castel, Maria Alexandre Dáskalos, Amélia Dalomba.

Ao lado dessa significativa produção poética feminina, vários poetas continuaram escrevendo. Lembro o nome de João Melo que vem publicando desde os anos 1980 e, embora não tenha saído das Brigadas Jovens, tem sido atuante na consolidação da poesia contemporânea angolana. João Melo foi Secretário da União dos Escritores Angolanos, tendo organizado o I Seminário da Literatura Angolana em dezembro de 1997, onde se discutiram os rumos da literatura de Angola. O erotismo em sua poesia é marcante e se faz arma de resistência para enfrentar medos e dores do passado e do presente povoados por fantasmas, pesadelos, gemidos. Poeta da paixão, elege o amor como forma de se manter vivo e de poder sonhar.

Outra vertente que caracterizou o panorama da poesia angolana pós-1980 foi a de poetas como Lopito Feijoó e Frederico Ningi, cuja linguagem poética rompeu iconoclastamente com os cânones estéticos tradicionais, valendo-se de metáforas dissonantes e experimentalismos visuais. Tais poetas assumiram claramente um viés poético paródico, transgressor e irreverente, através do qual denunciaram pesadelos sociais. Frederico Ningi, ironicamente, optou por uma poética, na qual palavras, imagens e símbolos gráficos interagem criticamente. Sua poesia sempre se mostrou discordante e agressiva.

Mais recentemente, em Luanda, como também tem ocorrido em diversas partes do mundo, começaram a surgir alguns movimentos de poesia performática: o grupo LEV'ARTE e o POESIA AO VIVO. Já há publicações desses jovens poetas: ControVerso é um livro de poesia de autoria de Kardo Bestilo, um dos pseudônimos literários de Kussi Bernardo, membro executivo do LEV'ARTE, grupo artístico que dramatiza poemas ao som de guitarra em bares da noite luandense. Dilemas, paradoxos existenciais e sociais, sentimentos são ali declamados e encenados.

\section{A Pintura em Angola, após a Independência}

Gostaríamos de poder abordar uma gama maior de obras literárias, mas como também iremos dar uma ideia da pintura em Angola pós-independente, trazemos aqui telas de alguns pintores angolanos que privilegiamos para esta apresentação: Eleutério Sanches,

4 TAVARES, 2001, pp. 16-17. 
Etona, Jorge Gumbe, Francisco Van-Dúnem, nos alongando um pouco mais na análise de telas dos dois últimos, em razão de as pinturas deles fazerem parte do corpus da pesquisa que desenvolvemos, no Brasil, junto à UFRJ e ao CNPq.

De Eleutério Sanches, convoco a alquimia da árvore [Tela 1], série em que o imbondeiro protagoniza a cena pictural, transbordando o espaço da tela, com majestática imponência e convulso cinetismo que expressam, plasticamente, a resistência africana, plasmada por intermédio de múltiplos entrelaçamentos e intensas cores. Como metáforas de vida, os galhos do imbondeiro apresentam oscilação propiciadora de uma imaginação em movimento; se assemelham a vigorosos tentáculos que alegorizam a força telúrica africana, cujas profundas raízes mergulham no chão ancestral, conotando resistência. Por trás das voluptuosas formas do imbondeiro, podem ser facilmente depreendidos o mistério e o encantamento próprio às histórias orais, contadas sob as árvores milenares da tradição. É, por conseguinte, evidente a presença de um gosto de narrar africano, que se expressa, picturalmente, pela revisitação de mitos e símbolos da terra, muitos dos quais reinventados, retorcidos, como os galhos dessa árvore sagrada, plasticamente representada.

Embora possua uma linguagem artística bastante diferente, Etona - nome artístico do pintor Tomás Ana, pertencente à "novíssima geração das artes plásticas angolanas" também partilha do prazer estético de reescrever Angola. É interessante como o tempo em que foi cartógrafo se reflete em sua pintura, cujos traços formam ângulos, desenhando mapas estéticos que põem em diálogo paisagens angolanas diversas, com cores contrastantes, reveladoras da pluralidade de geografias, etnias, costumes e crenças em Angola. [Tela 2] Conforme Adriano Mixinge, crítico e historiador de Arte, há, na obra de Etona, uma « poética do pontiagudo, das cores (avermelhadas e azuis) [que] se unem à poética da (re) memorização histórica e/ou morfológica, no intuito de (re)interpretação e modernidade (...) ». ( MIXINGE, Adriano)

A pintura de Etona realiza uma iconografia sociocultural de Angola, na medida em que pinta tipos humanos e cenários do país, com tintas de um pincel preocupado em dar visibilidade ao povo, em seu cotidiano; representa personagens anônimas, "sem rosto", que eterniza e problematiza em suas telas. Triangularizações delineiam uma cartografia pictórica plural, que contempla não apenas variadas paisagens e regiões de Angola, mas também personagens em movimento, em busca da própria identidade.

De Jorge Gumbe, invoco uma fase de sua pintura, que é caracterizada pela ressemantização do universo mítico luandense relacionado à Kianda. A água, o ar, o fogo, a terra e divindades de alguns dos sistemas mitológicos angolanos são presentes na obra desse pintor, principalmente na sua produção pós-1997, designada como "a fase dos imbondeiros e das Yàndà". Nas telas desse período, os elementos primordiais da natureza são reinventados segundo um estilo próprio e original. Com domínio das técnicas, o pintor recria mitos, tempos e temporalidades; gera, com traços leves, rápidos e com a dispersão das cores, figuras em rotação ascensional, que, em ritmo de fuga e antifuga, parecem se mover em rodopios que metaforizam o movimento giratório da criação, sempre em constantes mutações e metamorfoses dentro do universo.

O culto às Yàndà, nas populações quimbundas de Angola, é milenar, tendo continuado a existir secretamente, mesmo após a colonização, como forma de sobrevivência do imaginário mítico angolano. As Yàndà são entidades reguladoras de tudo que se relaciona ao oceano; são consideradas entes benéficos que alertam as pessoas para os perigos vindouros. Tanto podem ser representadas por peixes como por imbondeiros ou, também, pelo arco-íris e pelos flamingos (denominados ndeles em quimbundo), aves que metafo- 


\section{Conexão Letras}

ricamente simbolizam a esperança e o sonho, pois, segundo uma lenda, empurram a noite para o outro lado da Terra, de onde trazem o sol para iluminar os dias.

Nos quadros de Jorge Gumbe, frequentes espirais configuram a ideia de movimento em torno de imbondeiros que, antropomorfizados, bailam com galhos para o alto. Incorporando a sacralidade própria às Yàndà, a pintura de Gumbe realiza plasticamente um ritual telúrico de cores e míticas ofertas.

Vários críticos já ressaltaram esse vertiginoso movimento das imagens projetadas no espaço abstraizante das telas de Gumbe, como se as figuras pintadas captassem as ininterruptas metamorfoses do cosmo.

Em Oferendas para Kiàndà [Tela 3] é focalizado um típico ritual à deusa angolana do mar. Um imenso flamingo azul contracena com um imbondeiro humanizado que tem braços para cima e se agita ao vento. Tanto a árvore, como o pássaro são duplos míticos da Kyàndà e, como ela, simbolizam os sonhos, remetendo, por conseguinte, à busca dos sentidos poéticos da vida, à paz e à leveza da imaginação criadora. No coração do imbondeiro, nada uma tartaruga enorme, metáfora da ancestral sabedoria africana. Em acrobática posição, um ser humano tenta galgar uma escada para alcançar o corpo azulado e onírico do ndele, ave que, como o arco-íris, traz a magia das Yàndà.

Nessa perspectiva de reinventar mitos da tradição, fazendo-os interagir com modernas técnicas picturais, encontramos também a obra de Francisco Van-Dúnem. Suas telas recriam fábulas e estórias, provérbios e adivinhas, animais totêmicos da ancestralidade angolana e ideogramas desenhados na areia. Riscos das tradições dos povos da Lunda que, embora, em parte, fissuradas, devido aos longos anos de guerras e opressões, resistem ao tempo e se apresentam renovadas, por intermédio de traços híbridos que mesclam técnicas antigas de pintar com outras mais contemporâneas e universais.

Referindo-se à pintura de Van, Irene Guerra Marques declara que o pintor "projeta símbolos da ancestralidade numa contemporaneidade africana capaz de compatibilizar tradições com realidades atuais de Angola".

De acordo com José Redinha, os povos cokwe, antigos habitantes da Lunda, tinham o hábito de desenhar em terrenos arenosos; utilizavam o solo para explicar, graficamente, suas viagens, suas crenças, seus mundos, seus itinerários e seus mapas. Cartografar a terra era, para esses povos, uma forma de melhor conhecer o próprio solo identitário. Este era, assim, concebido como "mesa e assento", local onde se dispunham em círculo e aclaravam, com figuras traçadas na areia, suas conversas, costumes, conflitos, estórias, mitos. De um modo geral, esses povos usavam os dedos e o chão como se fossem, respectivamente, lápis e papel. Os desenhos na areia dos cokwe podem ser entendidos, portanto, como narrativas que "escrevem a terra angolana".

Ao optar por inserir ideogramas cokwe em suas telas, recriando-os em sua pintura, Van, com a plasticidade criativa de sua arte, empreende também uma reescrita de Angola, de seus ritos, mitos e práticas culturais.

Segundo Ana Paula Tavares, os desenhos em areia dos povos cokwe de Angola ilustram a íntima ligação entre os riscos e a palavra. Esta, na ancestralidade africana, acompanhava os movimentos de quem desenhava no chão. A palavra era, então, prenhe de magia e sacralidade. Havia uma harmonia intensa entre o que era contado e o traçado gráfico da estória na areia.

Com as imposições coloniais, as sucessivas guerras, as novas tecnologias, o contato com o desenho do risco foi-se perdendo. A arte de Van impõe-se, então, na modernidade, como uma forma consciente de tentar evitar perdas cada vez mais crescentes. Na obra do 
pintor, os animais totêmicos - a tartaruga, o antílope, o pássaro -, símbolos da tradição angolana, são motivos temáticos e, junto com os ideogramas na areia, servem para afirmar traços identitários angolanos que lutam para não serem totalmente apagados. Nos quadros do referido pintor, fábulas e palavras da tradição se fazem riscos, traços, imagens. Riscos na terra, sulcos profundos no chão das raízes. Riscos gráficos que buscam combater o risco das perdas.

Riscos, cores, linguagens: Arte. Pinceladas que se elevam no ar. [Tela 4] Pássaros e voos, metáforas da liberdade de uma escrita pictórica, que, enquanto produção artística, se descola do solo, ganhando altitude e densidade, ao mesmo tempo em que mergulha nas sombras da areia, à cata das próprias origens esmaecidas, em razão de tantos apagamentos impostos. Paisagens na areia, paisagens da memória, que retraçam caminhos da história, da cultura, preservando ritos ancestrais e traços identitários de povos originários de Angola.

Essa ideia do voo como imagem visual e plástica da liberdade artística está presente também nas telas de Van Dúnem. A figura do pássaro remete não só às asas da imaginação criadora, porém, também, à ludicidade dos desenhos na areia da arte tchókwe, cujo traçado constitui uma escrita pictográfica intimamente relacionada às tradições locais. Há, em Van, um labor da linguagem que contracena com marcas das tradições culturais dos povos da Lunda. Leveza e liberdade permeiam, assim, a pintura de Francisco Van Dúnem. Essa leveza, entretanto, não implica fuga da realidade. Em Van, o voo e o pássaro representam essa profunda engenharia da arte, estando relacionados à beleza estética, ao mistério da própria criação artística. Conclui-se, portanto, que, a par do desencanto e do desespero causados por tantos anos de guerra em Angola, a arte busca uma constante renovação estética por intermédio de um trabalho crítico e artístico.

Concluindo, observamos, de acordo com o filósofo camaronês Jean Bidima, que há, hoje, uma nova geopolítica das artes africanas, segundo as quais as africanidades devem ser entendidas como processo, estando sempre em travessia. Para Bidima, é preciso lembrar que os campos metafóricos das artes, atualmente, se encontram, de modo geral, em entrelaçamentos intermináveis que fundem e recriam, sem parar, tradições e modernidades. As artes trabalham, desse modo, com identidades e memórias em movimento. Daí, as recorrentes metáforas do retorcer e do caminhar, do rodopiar e do voar que, nas obras dos pintores analisados, expressam, plasticamente, não só a procura de identidades locais, mas também a busca de liberdades existenciais e estéticas mais amplas.

\section{Referências}

ABDALA Jr., Benjamin. Literatura, história e política. SP: Ática, 1989. AHMAD, Aijaz. Linhagens do presente. São Paulo: Boitempo Editorial, 2002. ANDRADE, Mário Pinto de. Antologia temática da poesia africana. Lisboa: Livraria Sá da Costa, 1975, v. I (Na Noite Grávida de Punhais) e V.II (Canto Armado). AUGUSTO, Rui. O amor civil. Luanda: União Cooperativa Editora, 1991. (Colecção Lavra \& Oficina, 92), $64 \mathrm{p}$.

BACHELARD, Gaston. O Ar e os sonhos. São Paulo: Ed. Martins Fontes, 1990. BARBEITOS, Arlindo. Angola, angolê, angolema. 2. Ed. Lisboa: Sá da Costa Ed., $197775 \mathrm{p}$.

. Nzoji (sonhos). Lisboa: Sá da Costa Ed., 1979. 54 p.

. Fiapos de sonho. Lisboa: Ed. Vega, 1992. 46 p. 
BIDIMA, Jean-Godefroy. Palabre, une juridiction de la parole. Paris: Edition Michalon, 1998. . L'art négro-africain. Paris: PUF, 1997.

CARVALHO, Ruy Duarte. A decisão da idade. Lisboa: Sá da Costa, 1976. 97 p. Observação directa. Lisboa: Cotovia, 2000. 126 p. In: António Ole: Retrospectiva 1967-1997 (Catálogo da Exposição). Luanda:

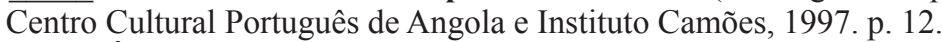

CRISTÓVÃO, Conceição. Amores elípticos (entre o amor e a transparência). Luanda: Edição do Autor, 1996.

ERVEDOSA, Carlos. Roteiro da literatura angolana. Lisboa: Edições 70, 1979. 164 p. FEIJOÓ, Lopito. (Org., selecção e notas). No caminho doloroso das coisas. Antologia de jovens poetas angolanos. Luanda: U.E. ${ }^{\mathrm{a}}, 1988.147 \mathrm{p}$.

Meditando (textos de reflexão geral). Luanda: Maboque, 1994.

FERREIRA, Manuel. Literaturas africanas de expressão portuguesa. SP: Ática, 1987. $220 \mathrm{p}$.

No reino de Caliban. Vol. 2. Lisboa: Seara Nova, 1976.

GIOVETH, Mena e SANTOS, Seomara. Nuvem passageira. Luanda: UEA, 2005. GONÇALVES, António. Buscando o homem. Antologia poética. Luanda: Kilombelombe, 2000. 127 p.

HALL, Stuart. Da diáspora: identidades e mediações culturais. Belo Horizonte: Ed. UFMG, 2003.

HAMILTON, Russell. Literatura africana, literatura necessária. Lisboa: Ed.70, 1981 e 1983. KAJIMBANGA, Víctor. A alma sociológica na ensaística de Mário Pinto de Andrade. Luanda: Instituto Nacional das Indústrias Culturais, 2000. 253 p.

KANDJIMBO, Luís. "Breve Panorâmica das Recentes Tendências da Poesia Angolana”. Austral Revista de Bordo da TAAG, no 22, 1997, p. 27.

Apologia de Kalitangi. Luanda: INALD, 1997. 245 p.

A Nova Geração de poetas angolanos. In: Austral. Revista de Bordo da

$\overline{\text { TAAG. }}$ N $^{\text {o } 22 . ~ L u a n d a, ~ o u t u b r o ~ a ~ d e z e m b r o ~ d e ~ 1997 . ~ p . ~ 21 . ~ T o t a l: ~} 61$ p.

LABAN, Michel. Angola: Encontro com escritores. Porto: Fundação Engenheiro António de Almeida, 1991. $2 \mathrm{v}$.

LARANJEIRA, Pires. Literaturas africanas de expressão portuguesa. Lisboa: Universidade Aberta, 1995.

LEITE, Ana Mafalda. Oralidades \& escritas nas literaturas africanas. Lisboa: Colibri, 1998. Literaturas africanas e formulações pós-coloniais. Lisboa: Colibri, 2003.

MAIMONA, João. As abelhas do dia. Luanda: UEA, 1990. 62 p.

Idade das palavras. Luanda: INALD, 1997. 87 p.

MARGARIDO, Alfredo. Estudos sobre literaturas das nações africanas de língua portuguesa. Lisboa: A Regra do Jogo, 1980.

MATA, Inocência. Literatura angolana: silêncios e falas de uma voz inquieta. Lisboa: Mar Além, 2001. 280 p.

Catálogo da Exposição Colectiva d e Pintura: António Óle, Jorge Gumbe, Massongi Afonso, Van. Luanda: Centro Cultural Português, 1999. p. 23.

MELO, João. Tanto amor. Luanda: UEA, 1989. 64 p.

O Caçador de nuvens. Luanda: UEA, 1993.

MENDONÇA, José Luís. Quero acordar a Alba. Luanda: INALD, 1997. 62 p. MESTRE, David. "Voz off". In: _. . Subscrito a giz: 60 poemas escolhidos (19721994). Lisboa: Imprensa Nacional- Casa da Moeda, 1996. 130 p.

Nem tudo é poesia. Luanda: União dos Escritores Angolanos, 1989. 77 p.

MIGNOLO, Walter. Histórias locais, projetos globais: colonialidade, saberes subalternos e pensamento liminar. Belo Horizonte: Ed. Da UFMG, 2003. 
MIXINGE, Adriano. Prefácio ao livro... na máscara do litoral, de Fernando Kafukeno. Luanda: Delegação Provincial de Luanda da Cultura, 1997. pp. 11-16.

NETO, AKIZ (Coordenador). O sabor pegadiço das impressões labiais. Huíla: Brigada Jovem de Literatura de Angola, 2003.

OLE, António. In: PEDRO, Francisco. "O Corpo da Pintura”. Jornal de Angola. Ano

24. N ${ }^{\circ}$. 7889. Vida \& Cultura: Suplemento de Artes, Letras e Ideias do Jornal de Angola. Lisboa, 20/06/ 1999. p. II.

PADILHA, Laura. "Cartogramas: Ficção Angolana e o Reforço de Espaços e Paisagens Culturais”. Revista Alea. Vol. 7, nº 1. Rio de Janeiro, jan.-jun. de 2005.

PANGUILA, António. O vento do parto. Luanda: s.Ed., 1993.

. Amor mendigo. Luanda: Governo Provincial de Luanda, 1997. 22 p.

PEDRO, Francisco. "O Corpo da Pintura". Jornal de Angola. Ano 24. No. 7889. Vida

\& Cultura: Suplemento de Artes, Letras e Ideias do Jornal de Angola. Lisboa, 20 de junho de 1999. p. III.

QUEIROZ, Carla. Os botões pequenos sonham com o mel. Luanda: INIC, 2001.

QUIJANO, Aníbal. “Colonialidade, Poder, Globalização e Democracia”. Revista Novos

Rumos. Ano 17, n³7. Caracas, 2002. pp. 4-28.

RUI, Manuel. Cinco vezes onze: poemas em novembro. Lisboa: Edições 70, 1985.

. In: SANCHES, Eleutério. UniVERSO transVERSO. Luanda: Nzila, 2003. p.9

SAID, Edward. Cultura e imperialismo. São Paulo: Companhia das Letras, 1995.

SANTANA, Ana de. Sabores, odores \& sonhos. Luanda: UEA, 1985. 47 p.

SANTIAGO, Silviano. Uma literatura nos trópicos. São Paulo: Editora Perspectiva, 1978.

SANTOS, Boaventura de Sousa. "Entre Próspero e Caliban: colonialismo, pós-colonialismo e inter-identidade”. In: RAMALHO, Irene e RIBEIRO, António Sousa (Organizadores). Entre ser e estar: raízes, percursos e discursos da identidade. Porto: Afrontamento, 2002.

SANTOS, Milton. A natureza do espaço. Técnica e tempo. Razão e emoção. 2. Ed. São Paulo: Hucitec, 1997.

SECCO, Carmen Lucia Tindó. Antologia do mar na poesia africana do século XX. Angola. Luanda: Editorial Kilombelombe, 2000. 257 p.

. A Magia das letras africanas. Rio de Janeiro: ABE Graph Editora, 2003.

SEPÚlVEDA, M. C. e SALGADO, M. T. África \& Brasil: Letras em laços. Rio: Ed. Atlântica, 2000. $351 \mathrm{p}$.

SERRANO, Mafalda. Catálogo Viteix: obras de 1958 a 1993. Culturgest, março 2004 http://www.mafaldaserrano.com/introt_tarotart/catalogos/protected_ld_catalogv_p.htm

SOARES, Francisco. Notícia da literatura angolana. Lisboa: Imprensa Nacional-Casa da Moeda, 2001. $352 \mathrm{p}$.

. (org.) Antologia da nova poesia angolana (1985-2000). Lisboa: Imprensa Na$\overline{\text { cional }}$ - Casa da Moeda, 2001.

TALA, João. O gasto da semente. Luanda: INIC; Instituto Nacional das Indústrias Culturais, 2000. (Colecção “A Letra", 2a. Série, no 19), 23 p.

. Lugar assim. Luanda: UEA, 2004.

. A Vitória é uma ilusão de filósofos e de loucos. Luanda: União dos Escritores

Angolanos, 2005.

TAVARES, Ana Paula. O sangue da buganvília. Praia; Mindelo: Embaixada de Portugal; Centro Cultural Português, 1998. p. 49.

. Ritos de passagem. Luanda: UEA, 1985. 36 p.

O lago da lua. Lisboa: Caminho, 1999. 55 p.

VASCONCELOS, Adriano Botelho. Abismos de silêncio. Luanda: União dos Escritores Angolanos; ABV Editora, 1996. 40 p. 


\section{Conexão Letras}

\section{Anexos:}

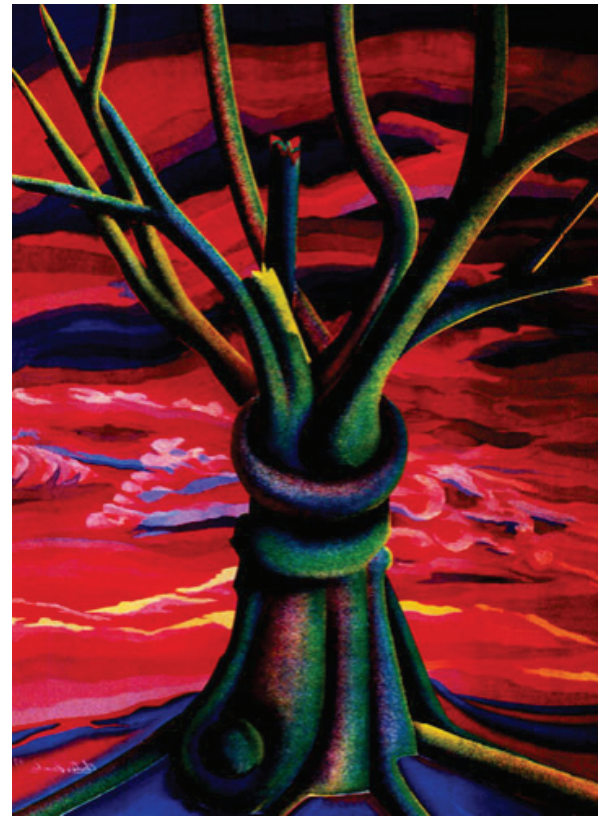

Tela 1: Eleutério Sanches

"Alquimia da árvore" (motivação Imbondeiro)

Técnica: óleo têmpera sem tela - Ano: 1991

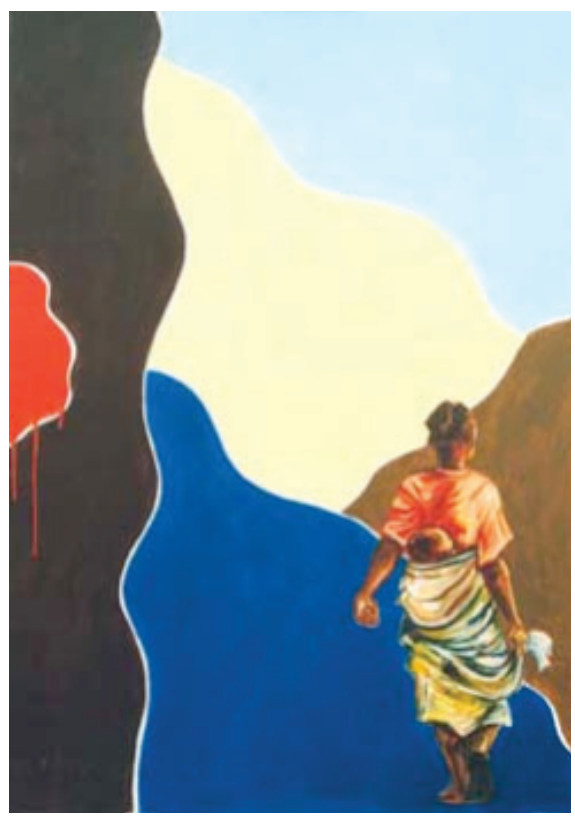

Tela 2: Etona

Sem título. Técnica: óleo sobre tela

Sem data 


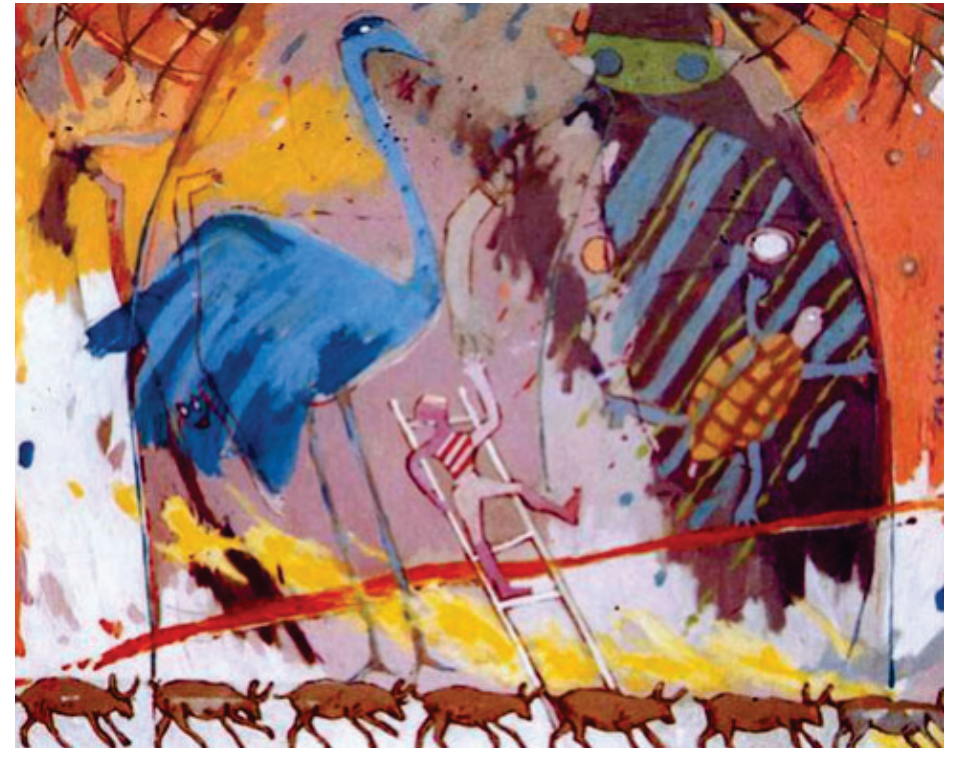

Tela 3: Jorge Gumbe

"Oferendas para Kiàndà". Técnica: acrílico sobre tela Ano: 1999

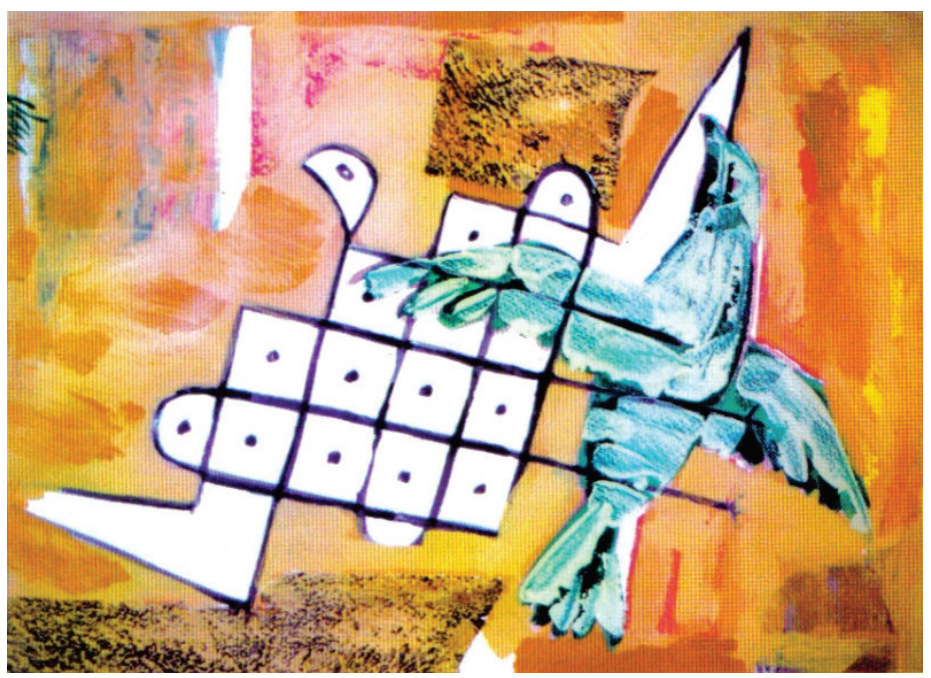

Tela 4: Francisco Van Dúnem

Ideograma versus realismo - Ave em voo I

Técnica: mista s/ papel

Dimensões: 70 x $50 \mathrm{~cm}$

Ano: 2001 